in certain regions is governed by the moisture content of the epidermis.

Measurements of emissivity using a Hilger double-beam spectrograph indicate that beyond $6 \mu$ the epidermis acts as a black-body, in agreement with the foregoing calculations, thus indicating that in general these conclusions are correct (Fig. 2).

Hilger and Watts, Ltd.,

$$
\text { R. ELAM }
$$

London, N.W.1.

Royal Radar Establishment, Malvern,

Middlesex Hospital, London, W.1.

${ }^{1}$ Hardy, J. D., J. Clin. Invest., 13, 615 (1934). 2 Derksen, W. L., Monahan, T. I., and Laws, A. J., J. Opt. Soc. Amer., 47,
995 (1957).

${ }^{3}$ Bettley, F. R., and Donoghue, E., Nature, 185, 17 (1960).

4 Rosenberg, B., J. Chem. Phys., 36, 816 (1962).

\section{Thiocyanate-level in the Serum and Thyroid of Cows from Areas with Different Intensities of Goitre in Human Beings}

THE results of recent investigations suggest that the genesis of endemic goitre in different countries is caused not only by iodine deficiency in food, but also by antithyroid compounds contained in different plants. Several goitrogenic compounds are so far known: 1-5-vinyl-2thiooxazolidone (goitrin) ${ }^{1}$, polysulphides ${ }^{2}$ and thiocyanates ${ }^{3,4}$. These last-named can be formed from cyanoglucosides contained in larger quantities in some species of white clover ${ }^{5}$.

The following compounds may be considered also as being goitrogenic: 'arachidoside' glucoside in groundnut shells ${ }^{6}$; cheiroline in wallflowers (Cheiranthus cheiri) which, in the rumen of sheep, can be transformed into thiourea derivatives?

Although the action of polysulphides and thiocyanates is considered as being less goitrogenic than, for example, that of goitrin, they can be just as dangerous owing to their presence in large amounts.

Šlinik and Maršikovás found an increase in thiocyanate content in the blood serum of inhabitants of goitrogenic areas. Podoba et al. ${ }^{8}$ discovered a positive correlation between the SCN- content in investigated vegetables and the thyroid weight of animals consuming them. Greene et al..$^{10}$ examined the goitrogenic action of milk from cows fed on white clover.

Our investigations were carried out on 200 cows destined to be fattened, originating from areas of varying intensities of goïtre in human beings.

Thiocyanates were estimated in blood plasma and in the thyroid extract. This extract was obtained in the following manner: twice-distilled water (l ml.) was added to $1 \mathrm{~g}$ of freshly prepared thyroid tissue and then homogenized. A small amount of this homogenate was centrifuged for $15 \mathrm{~min}$ at 15,000 r.p.m. at room temperature. $0.5 \mathrm{ml}$. of liquid from the sediment was collected for analysis. Thiocyanates in the blood plasma and thyroid extract were determined by means of Aldridge's method 11,12 .

Some of the results are presented in Table 1.

Table 1. Thiocyanate Content in Blood PLASMa AND Thyom Extract FROM AN AREA WITH VARYING INTENSITIES OF GOITRE IN HUMAN BEINGS

\begin{tabular}{|c|c|c|c|c|c|}
\hline rea & $\begin{array}{c}\% \text { of } \\
\text { goitre in } \\
\text { humans } \\
(\%)\end{array}$ & $\begin{array}{l}\text { No. of in- } \\
\text { vestigated } \\
\text { cows } \\
\text { (ind.) }\end{array}$ & $\begin{array}{c}\% \text { of thyroids } \\
\text { weighing more } \\
\text { than } 24 \mathrm{~g} \text { in } \\
\text { cows } \\
(\%)\end{array}$ & $\begin{array}{c}\text { SCN- content } \\
\text { in blood } \\
\text { plasma of } \\
\text { cows } \\
(\mu \mathrm{g} / \mathrm{ml} .)\end{array}$ & $\begin{array}{l}\text { SCN- content } \\
\text { in the thyroid } \\
\text { extract of } \\
\text { cows } \\
(\mu \mathrm{g} / \mathrm{ml} .)\end{array}$ \\
\hline $\begin{array}{l}\text { I } \\
\text { III }\end{array}$ & $\begin{array}{c}0-31 \\
31-50 \\
51\end{array}$ & $\begin{array}{r}70 \\
100 \\
30\end{array}$ & $\begin{array}{l}25 \cdot 7 \\
33 \cdot 0 \\
70 \cdot 0\end{array}$ & $\begin{array}{l}3 \cdot 1 \pm 1 \cdot 7 \\
3 \cdot 1 \pm 2 \cdot 0 \\
4 \cdot 5 \pm 1 \cdot 4\end{array}$ & $\begin{array}{l}3.4 \pm 1.7 \\
4.3 \pm 2.0 \\
5.8 \pm 1.8\end{array}$ \\
\hline
\end{tabular}

Statistical analysis: $*$ I and III, $P<0.001$; II and III, $P<0.001$
An increased amount of thiocyanates was noted in thyroids in which cysts appeared. Their content was $7 \cdot 49 \pm 1.4 \mu \mathrm{g} \mathrm{SCN}-/ \mathrm{ml}$. of thyroid extract. Statistical analysis showed a high significance difference $(P<0.001)$ between the thiocyanate content in cystoid thyroids and those without cysts. The correlation coefficient for thyroid weight (the ratio: $\frac{\text { thyroid weight(g) }}{100 \mathrm{~kg} \text { live weight }}$ was used for analyses) and thiocyanate content in the thyroid extract was $r=+0 \cdot 67$. The correlation coefficient for the SCNlevel in blood plasma and the SCN- content in the thyroid extract was $r=+0 \cdot 44$. The last correlation coefficient turned out to be highly significant $(P<0.001)$.

It should be noted that well-known goitrogenic plants, such as Swedish turnip, appear frequently in the investigated areas. Earlier investigations ${ }^{13,14}$ have also shown a lower iodine content in water and milk from areas with a greater goitre intensity in human beings (Table 2).

T'able 2. Mean IoDine-Level in Water and MILK From an AREa with VARYING INTENSITIES OF GOITRE IN HOMAN BIN A

$\begin{array}{rcc}\text { Area * } & \begin{array}{c}\text { Iodine in water } \\ (\mu \mathrm{g} \%)\end{array} & \begin{array}{c}\text { Iodine in milk } \\ (\mu \mathrm{g} \% \circ)\end{array} \\ \text { II } & 4 & 3 \\ \text { II } & 2-4 & 2-3 \\ \text { III } & 0-2 & 0-2 \\ & * \text { See Table } 1 . & \end{array}$

The results obtained suggest that thiocyanatesamong other factors (as, for example, the lack of iodine) - provoke an abnormally enlarged thyroid in cattle, or that they can appear as an accompanying compound and an indicator of other sulphuric compounds having goitrogenic effect ${ }^{3}$.

S. BOBEK

Department of Animal Physiology,

A. Pelczarsika

College of Agriculture, Cracow, Poland.

${ }^{1}$ Astwood, E. B., Greer, M. A., and Ettlinger, M. G., J. Biol. Chem.,181, 121 (1949).

${ }^{2}$ Jirousek, L., Endokrinologie, 33, 310 (1956).

${ }^{3}$ Langer, P., and Michajlovskij, M., Hoppe-Seylers Z. Physiol. Chem., 312, 31 (1958).

' Langer, P., Nature, 185, 174 (1960).

${ }^{5}$ Flux, D. S., Butler, G. W., Johnson, J. M., Glenday, A. C., and Petersen, G. B., N.Z. J. Sci. Tech., 38, 88 (1956).

'Moudgal, N. R., Srinivasan, V., and Sarma, P. S., J. Nutr., 61, 97 (1957).

${ }^{7}$ Bachelard, H. S., and Trikojus, V. M., Nature, 185, 80 (1959).

8 Silinik, K., and Maršiková, L., Nature, 16', 528 (1951).

' Podoba, J., Samel, M., Stukovský, R., and Michajlovskij, N., Bratisl. Lek. Listy, $3 \%$, No. 2 (1957).

${ }^{10}$ Greene, R., Farran, H., and Glascock, R. F., J. Endocrinol., 17, 272 (1958).

${ }^{11}$ Aldridge, W. N., The Analyst, 69, 262 (1944).

12 Aldridge, W. N., The Analyst, 70, 474 (1945).

${ }^{13}$ Ewy, Z., Bobek, St., and Kamiński, J., Roczn. Nauk Roln., 79-B-3. 312 (1962). ${ }^{14}$ Ewy, Z., Bobek, St., and Kamiński, J., Post. Hig. Med. Dośw., 16, 335

\section{Action of $\gamma$-Aminobutyric Acid on Cancer borealis Muscle}

IN several crayfish preparations ${ }^{1-5} \gamma$-aminobutyric acid (GABA) mimics the natural inhibitory transmitter. Moreover, it has recently been found in large amounts in Cancer borealis peripheral nerve and muscle ${ }^{6}$, suggesting a possible role as inhibitory transmitter. The action of GABA on $C$. borealis muscle has not been examined. It has been reported that GABA has no inhibitory effect on $C$. anthonyi muscle ${ }^{7}$ and that it blocks excitatory junctional potentials in $C$. magister muscle while scarcely changing membrane conductance ${ }^{8}$. Thus, it seemed of interest to investigate the action of GABA on $C$. borealis muscle.

Two microelectrodes were inserted into the superficial muscle fibres of the 'opener' or 'closer' of the dactyl of the walking leg. One, filled with $3 \mathrm{M}$ potassium chloride, recorded resting potential; while the other, filled with 3 M potassium citrate, altered membrane potential by 